\title{
THE INTERNATIONAL CRIMINAL COURT (ICC), IMPUNITY AND THE RISE OF A SIEGE MENTALITY AMONG KENYA'S KLEPTOCRACY ${ }^{1}$
}

Westen K Shilaho²

\section{Introduction}

How has the ICC influenced Kenya's politics following the naming of six prominent Kenyans in 2010 that the local media referred to as the 'Ocampo Six', suspected masterminds of the 2007-2008 postelection violence? The entry by the ICC into Kenya's violently disputed elections in 2007 unsettled Kenya's political elite attuned to impunity so much that Uhuru Kenyatta and William Ruto presented a joint presidential candidacy during the 2013 elections under Jubilee coalition, cynically referred to as the "alliance of the accused", so as to try and gain leverage over the ICC. An attempt by the ICC to accord justice to victims of atrocities committed during disputed elections in 2007, was the first frontal confrontation against impunity deeply entrenched in the country's body politic owing to ethnicised politics, compromised judiciary and weak and even dysfunctional institutions. Kenya's judiciary is yet to evolve into an independent institution following years of interference by the executive dating back to the one party autocracy. However, despite expectations among a section of Kenyan populace that the ICC would deliver justice to the victims of egregious human rights violations, this was not to be. The hope that the ICC would dent impunity normative in the body politic remains a mirage. Kenyatta and Ruto politically exploited their charges at the ICC and by so doing exacerbated ethnic polarisation. Confronted by an unprecedented legal hurdle, Kenyatta and Ruto formed an ethnic alliance, ascended to power

I The financial assistance of the National Research Foundation (NRF) towards this research is acknowledged.

2 Institute for Pan-African Thought and Conversation, University of Johannesburg, Johannesburg, South Africa. E-mail:wshilaho@gmail.com 
on a joint presidential ticket and reinforced ethnicity, a vector for political mobilisation and consequent violence since Kenya's return to multiparty politics in I99I. Although instrumentalisation of ethnicity for political gain predates Kenya's independence in ${ }_{19} 63$, the deleterious interface of ethnicity, contestation for power and economic opportunities gained a foothold under Jomo Kenyatta, Kenya's first president (1963-I978) (Karimi and Ochieng I980). Since December 2010, when six Kenyan suspects were named as masterminds of the 2007-2008 postelection violence, the ICC remains an overarching variable in Kenya's politics owing to elusive accountability for atrocities committed in the wake of the disputed presidential results in 2007.

The disputed 2013 presidential victory by Kenyatta and Ruto, at the time indicted by the ICC, raised questions pertaining to the rule of law, normative and inclusive politics based on accountability and probity that the 2010 Constitution was expected to make part of Kenya's political culture. Implementation of the constitution has faced impediments since promulgation because Kenyatta, an offshoot of Kenya's plutocracy, stands to lose in the event a reformed state comes into being. This sense of self-preservation is untenable because Kenya's stability depends on establishment of the rule of law and justice. The collapse of Kenya's two cases before the ICC, the first against Uhuru Kenyatta and the second against William Ruto and Joshua Sang, preceded by dropping of charges against three other suspects, is two pronged. It exposes deficiencies of the ICC, a legal as well as political institution. It also illustrates the vulnerability of the ICC before suspects that are powerful state actors. Such accused easily maximise control of state apparatus to torpedo the course of justice for victims of mass atrocities. Kenyans that initially invested confidence in the ICC as a dispenser of justice are forced to have second thoughts.

Inability by both the local judiciary and the ICC to identify and prosecute masterminds of the 2007-2008 atrocities, poses a threat to Kenya's democratisation process. As a Court of last resort, the ICC intervened because Kenya was unable and unwilling to try those liable for organising and perpetrating the violence. Lack of political will is linked to Kenya's unresolved historical injustices such as political assassinations, state sponsored violence, land dispossession and related ethnic violence, economic crimes, and endemic corruption. The realisation of the constitution of Kenya 2010 is a culmination of efforts for state restructure spanning the entire postcolonial period. The absence of political will poses the greatest threat to Kenya's stability. Uhuru Kenyatta's reluctance to facilitate implementation of the constitution and the Truth Justice and Reconciliation Commission (TJRC) report are illustrations of hostility against both retributive and 
restorative justice. The report was submitted to Kenyatta in 2013 amid allegations of doctoring. The office of the president was accused of exerting pressure on local commissioners to expunge sections of the report that adversely implicated Jomo Kenyatta in historical land injustices across the country (The Star June 4 2013. To date the report lies in abeyance. Neither has the report been widely circulated to the public as stipulated by the law. The report presents a case of conflict of interest to Kenyatta, son of Kenya's first president. The report adversely mentions Kenyatta and Ruto in relation to the 2007-2008 postelection violence although no recommendations were made against them (The Final Report of the TJRC of Kenya 20I3; The Star June 3 2013).

The notion that resolution of Kenya's postcolonial upheavals might lie with the international community through institutions such as the ICC is misplaced. In fact such an approach could prove inimical to Kenya's stability, a country historically sharply divided along ethnic lines. At the same time it can be argued that institutionalised impunity owing to blatant disregard for the rule of law and exploitation of violence for political and economic advantage poses a risk to Kenya's stability unless checked. Impunity has entrenched a culture of violence in the country's politics because those who engage in violence invariably get away with it. Insidiously they are rewarded with appointment or election to public office. Of concern is that Kenya's judiciary has proven ineffective throughout the country's independence. It is even complicit in the edification of impunity by focusing on crimes by poor and less influential people while ignoring crimes by high and mighty or even shielding such people from accountability despite evidence of errant behaviour. In what seems to be a grotesque inversion of events, the judiciary seems to protect the powerful from the powerless. Kenya's democratisation is precarious because of lack of impartiality in the application of the rule of law. Despite some judicial reform following the post-election violence, the judiciary has not yet won wider appeal as a disinterested arbiter of political and other disputes because of corruption, tribalism and partisanship (IWPR April I7 20I4).

The article is seminal in the sense that it analyses the nexus of Kenya's indigenous capital, spoils politics, violence and elusive justice. It shows how this linkage played itself out in international criminal justice and Kenya's international relations following the naming of Kenyatta, Ruto and others as masterminds of crimes against humanity during the 20072008 postelection violence. Kenya's engagement with the ICC prominently thrust Kenya's domestic politics into African and international politics owing to the indictment high profile politicians. Daniel Moi, Kenya's second president and Jomo Kenyatta's longest serving vice president, politically 
mentored both the younger Kenyatta and Ruto. He inherited a one party autocracy, that he sustained through institutional collapse and deft manipulation of ethnicity. The joint presidential candidature of Kenyatta and Ruto was backed by Mwai Kibaki, Moi's successor and vice for a decade. Unable to change Kenya's political and economic trajectory, Kenya almost plunged into civil war under Kibaki over disputed presidential elections following heightened ethnic polarisation. Kenyatta-Moi-Kibaki political axis dominates Kenya's politics and is the nucleus of local capital owing to its vast economic interests traversing the entire economic gamut. Kenya's politics and economic control is in a grip of a tiny coterie of individuals related by blood, economic interests and more insidiously by their ability to mobilise ethnically for further economic and political gain. This plutocracy is impervious to accountability and wary of the ICC. In Kenya's political system, the personal, here used to mean selfish economic interests, the communal and the political are intertwined and reinforce neopatrimonialism. In this polity, the political elite exploit local and communal anxieties, cultural differences, even primordial ones, and genuine concerns for personal gain. It was against this background that Kenyatta and Ruto easily mobilised their respective tribes against the ICC and opponents by turning personal legal woes into communal and then national threats and burdens. The two politicians were central to Moi's ill-fated so-called generational transition in 2002. Then Moi unsuccessfully tried to hoist Kenyatta, a political neophyte, on Kenyans as his successor. Although the ICC rendered the ethnic alliance between Kenyatta and Ruto a matter of political survival, Kenyatta and Ruto could easily enter into an entente ahead of the 2013 elections because both are of the ancien régime extraction (Shilaho 2013).

The article highlights a treacherous terrain in which politics and international criminal justice coalesce. A legal analysis of the ICC with a specific focus on the Kenyan cases is not what this article is about. It is confined to the politics of the cases specifically the cynical manipulation of the cases by tribal barons at the expense of justice. The ICC legal threat made Kenya's kleptocracy feel besieged. It compelled Kenyatta and Ruto, who were on opposing sides during the disputed 2007 elections, to form an ethnic alliance between Kikuyu and Kalenjin, their respective tribes. It did not matter that these politicians were indicted for allegedly mobilising gangs from their respective ethnic groups to commit atrocities against 'enemy tribes', in effect each other's supporters, during the ensuing ethnic violence. Ruto was indicted for mobilising "Kalenjin warriors" to drive Kikuyu out of the Rift Valley region while Kenyatta was indicted for mobilising and sponsoring a rag tag Kikuyu militia, mungiki, to retaliate against opposition supporters, who included members of Luhya, Luo and Kalenjin ethnic 
groups in Naivasha and other Kikuyu dominated parts of the Rift Valley. Consequently the two were separately charged as co-perpetrators in crimes that included organising and financing murder, displacement, persecution, rape and other inhuman acts committed during the post-election violence (ICC 20I5a; ICC 20I3b).

Victory for Kenyatta and Ruto during the 2013 elections was indispensable. It was required to salvage their political careers, evade possible incarceration and defend the economic and political interests of Kenya's plutocracy. A combination of these three factors trumped the Constitution, and specifically Chapter six on leadership and integrity that demanded high moral and ethical standards for those aspiring for and occupying public office. Once the high court and electoral body cleared Kenyatta and Ruto to vie for the highest office in the land despite facing egregious criminal charges, the moral bar that the constitution was expected to instil in the country's politics and public life did not see the light of day.

In the second section, I argue that Kenyan politics thrives on personal rule logic that undergirds politics across Africa. The ICC politics dovetailed with ethnicity to determine the outcome of Kenya's 2013 elections ${ }^{3}$. The section does not intend to portray Kenya and Africa as undifferentiated but to underscore the notion that the individual operates within the communal and this largely affects politics in Sub-Saharan African. It is for this reason that Kenyan politicians are able to mobilise along tribal fault lines to win elections and even evade justice. Save for South Africa, to name but one, African polities are largely rural, and peasantry. Consequently, workers and peasants seem to lack consciousness to mobilise along crosscutting interests and challenge the predatory political elite. The influence of kinship politics characterised by clanism, ethnicity, regionalism and religion trumps horizontal political organisation and mobilisation. The fusion of society and state makes it hard for politics to be organised along crosscutting interests. This logic puts into perspective the controversial ascendancy of Kenyatta and Ruto to power despite facing criminal charges before the ICC.

In Kenya, a culture of impunity is deeply entrenched as seen through lack of political will to prosecute those responsible for vicious cyclic tribal violence in the I990s and specifically the masterminds of the 2007-2008 atrocities. The ICC intervened in Kenya under the principle of complementarity, because Kenya was "unable and unwilling" to prosecute high ranking state officials implicated in atrocities committed during the 2007-2008 postelection violence in which an estimated I 333 people were killed and over 600000 displaced (Republic of Kenya 2008a). Even among

3 For a nuanced analysis of Kenya's 2013 elections see Shilaho 2013. 
the low and middle level perpetrators none has been prosecuted (Brown and Sriram 20I2; Human Rights Watch 2OII).

In the subsequent sections, I focus on the nexus between politics and international criminal justice, the Kenyan situation at the ICC and highlight duplicity among Kenya's politicians through a Special Tribunal for Kenya versus The Hague debate. Initially some politicians publicly expressed preference for the ICC option, including Ruto. Some of these politicians even voted against and defeated an amendment bill, and effectively the Special Tribunal for Kenya Bill. The bill would have anchored the tribunal in the Constitution to cushion it against executive manipulation. Opponents of a local mechanism for resolution of the conflict expediently changed tune and identified scapegoats once the ICC swung into action. They accused the Court of imperial tendencies and meddling in Kenya's internal affairs, thus its sovereignty. In Kenya's deeply ethnically divided society, "truth" concerning the narrative of the post-election violence was lost during the 2013 elections campaigns that, like previous ones, specifically since the advent of multiparty politics, dangerously split the country into ethnic enclaves. So highly politicised did the ICC cases become that the question of justice for victims became disputable, if not, non-existent in the whole controversy.

\section{The Logic of African Politics}

According to Chabal and Daloz (I999) the importance of vertical links and the notion of the individual are salient in African politics. In the estimation of the two Africanists, the individual rationality in Sub-Saharan African polities is based on the communal logic. This means that in as much as Africans act in their individual capacities, their behaviour is greatly influenced by the mores, values and norms of the communities in which they exist. It is for this reason that Chabal and Daloz observed that students of African politics cannot understand how politics operates in Africa sui generis, in and of itself, divorced from the rest of the society. This is because African polities have their own logic even if it appears perverse and inimical to people's wellbeing. The communal logic entails political behaviour that citizens in consolidated democracies would not easily understand (Chabal and Daloz I999: I55). Firstly, the individual acts in concert with the psychological, social and religious foundations of the local community. Secondly, relations of power in Africa depend on a shared notion that the political is communal (Chabal and Daloz 1999: 156). This explains why democracy and multiparty elections are seen in the context of communal rather than individual mould characterised by competing manifestos and 
visions for a country. These manifestos are elaborate on issues concerning the electorate but even these are read through the prism of tribal, clan, regional and religious fault lines. Kenya's elections reflect tribal voting patterns akin to an ethnic census since kinship and tribal ties override cross cutting social, political and economic concerns (Shilaho 20I4). Once a politician has the command of his ethnic group, he considers himself or herself as influential in national politics on that very basis but not on the strength of their programmatic politics. Superficially, the controversial results of the 2013 elections despite crimes against humanity charges against Kenyatta and Ruto would imply that majority of Kenya's voted against their interests by disregarding questions of probity, accountability and justice. However, the link between the personal, the communal and the national in this polity illuminates the outcome of the 2013 elections.

The intention here is not to allude to a herd mentality among Kenyan voters and overlook the role of manifestos and policies. The argument is that even economic and social concerns are aggregated along ethno-regional fault-lines and invariably the ethnic affiliations of candidates, especially presidential ones, matter more than the issues they purport to champion. The ethnicity factor remains overarching during presidential elections in spite of devolution of some power and resources to the periphery, county governments, under the 20I0 Constitution because the centre has not sought to de-ethnise the politics (Shilaho 2015). Regionalism, that in most cases overlaps with ethnicity, and religion are other axes for political mobilisation. Hyden argues that the salience of "community-centred networks" in African politics stems from the inability of class-based identity politics to emerge and dislodge kinship ties (Hyden 2006: 55). Jackson and Rosberg (I984: 42I) identify such a political system as personal rule defined as "a distinctive type of political system in which the rivalries and struggles of powerful and wilful men, rather than impersonal institutions, ideologies, personal policies, or class interests, are fundamental in shaping political life".

Chabal and Daloz (1999: 158) argue that the act of voting in multiparty elections must be seen as part of informal relations of political exchange that has a direct bearing on the results. The electorate vote for 'one of their own', that is, an ethno-regional presidential candidate in anticipation of disproportionately benefiting from public goods colloquially referred to as "development" or "national cake" in Kenya's political parlance once he or she ascends to power. Although Africa's politics is mostly affected by vertical links, this is not unique to Africa. What distinguishes Africa is that this is a compelling factor, 
What is significant in Africa is the extent to which vertical and/or personalised, relations actually drive the very logic of political system. It is not just that politics are swayed by personal considerations or that the personal is manipulated for political reasons. It is also, and perhaps more importantly, that the overall aim of politics is to affect the nature of such personal relations (Chabal and Daloz I999: 158).

\section{The ICC, Neopatrimonialism and Tribal Mobilisation}

Owing to the influence of neopatrimonialism, it was not possible for Kenyan politicians to regard the ICC cases as strictly legal issues. This does not imply that the ICC is a purely legal institution. Being a multilateral institution and given that the Rome Statute allows the United Nations Security Council (UNSC) to refer cases to the ICC and defer those before it, it is untenable to describe the ICC as a purely legal institution. Kenya, a country in which politics is not institutionalised, politicians cynically invoke identity, and specifically, ethnicity, to plead victimhood and evade accountability. Unchecked for long, the practice has precipitated institutional atrophy and endemic impunity. Kenyatta, Ruto and supporters accused the ICC of targeting Kikuyu and Kalenjin ethnic groups. They reduced the 2013 elections to a referendum on the ICC. They interpreted their victory as repudiation of the ICC and assertion of Kenya's sovereignty.

The two politicians easily mobilised ethnically because the society spills over into the state. Tribalism coupled with patronage-clientelism, a variant of neopatrimonialism, defines Kenya's political system. In neopatrimonialism, the patron or "Big Man" often the president, exercises authority through rewards to his clients. These clients are the "Big Man's" supporters whose influence and power are hinged on loyalty to the "Big Man" and ethno-regionalism. They prop up the "Big Man" through mobilisation of co-ethnics to vote for the incumbent or a rival in case of a fall out with the incumbent and defend the regime no matter what. Rewards come in the form of appointments in the bureaucracy, extraction of rents through government tenders and even the right to act with impunity. This political behaviour is also known as prebendalism (van de Walle i994: I33-I34; Hyden 2006: I02). In the Kenyan political context, these rewards almost exclusively go to allies from the president's ethnic group pivotal in defending one of "our own" against losing power to "enemy" tribes.

\section{Rent Seeking and Accountability}

Rent seeking is the raison d'etre of spoils politics and refers to a 
situation in which the ruler, in concert with a clique of allies, take advantage of control of the state to illicitly benefit themselves through prebends (van de Walle 1994: I33-I34; Widner I994: 53). Neopatrimonialism nurtures impunity, entrenches patronage, corruption and undermines the rule of law thus rendering state institutions dysfunctional since it thrives on a rigid dichotomy of "Big Men-Little People” (Russell I999). The cumulative effect of this divide on democratic consolidation in Kenya is deleterious. "Big Men" and their allies maintain a grip on power, perpetrate rent-seeking politics and act with impunity as they balkanise the polity into tribal enclaves. A sense of false consciousness makes the poor to think that tribal politics is beneficial to them and cannot mobilise collectively to enforce accountability on predatory politicians (Jackson and Rosberg I984).

Expounding on the personal rule logic, Chabal and Daloz (I999: I6I) are of the view that ultimately the legitimacy of neopatrimonialism depends on the ability of the "Big Man" to deliver on expectations of clients in micro-networks of patronage and clientelism. The national good is subsumed under the immediate gratification of the clients at the expense of development programmes. The "Big Man's" continued stay at the helm depends on the sustenance of these networks even if they cause adverse economic consequences including poverty for the rest of the society (Chabal and Daloz I999: I6I). The one party statism was defined by state personalisation and privatisation of the economy. The corollary was removal of oversight bodies to check excesses attendant to exercise of power by the "Big Man" who officially carried the designation, president. Despite a shift from single party to multiparty politics, the one party rule legacy still influences Kenya's politics. Attributes of this legacy include criminalisation of basic freedoms such as freedom of expression, assembly, protest and disregard for the rule of law. As such, Kenya's polity is archetypal of the unique communal logic that undergirds sub-Saharan African politics. South Africa's history of apartheid and the presence of a significant white population in the country make it untenable to analyse its politics in the same prism as the other countries in this region. The inability of Kenya to organise politics along cross cutting interests has seen the evolution of politicised ethnicity into the ideology of "tribalism" that renders institutions germane for a functioning democracy dysfunctional.

Personal rule defined Africa's autocratic single party rule and military dictatorships and still holds sway in Kenya under multiparty politics because of continued informalisation rather than institutionalisation of politics. It is inconceivable that in a rational legal authority, a person accused of crimes against humanity charges could be eligible to stand as a presidential candidate, let alone a controversial victory by a joint presidential ticket by 
two ICC indictees. Such charges would most likely deal a death knell to the political career of the accused in a polity informed by the rule of law and normative leadership. A rational legal authority is the polar opposite of personal rule. The former is a polity in which "the public sphere is carefully distinguished from the private sphere; written laws and bureaucratic institutions routinise the exercise of authority and protect individuals and their property from the whims of capricious leaders" (Bratton and van de Walle i997: 62).

\section{The ICC and its Disputed Legitimacy}

The Nuremberg and Tokyo trials, international criminal tribunals, such as the International Criminal Tribunal for Rwanda (ICTR), the International Criminal Tribunal for Yugoslavia (ICTY) and the Special Court for Sierra Leone (SCSL), The Extraordinary Chambers in the Courts of Cambodia (ECCC) or Cambodia Tribunal or Khmer Rouge Tribunal among other judicial processes preceded the permanent legal institution, International Criminal Court (ICC). The Nuremberg and Tokyo trials showed that international criminal justice helps in securing peace by delegitimizing and incapacitating spoilers. The flipside is that this very aspect of international criminal justice makes the ICC a portent instrument of warfare that escalates rather than mitigates conflict (Nouwen 20I3: I77). Kastner shares the same position and observes that the ICC “... has the potential to contribute to ending grave crimes but also bears the danger of prolonging a conflict by adding to the insecurity of the warring parties" (Kastner 20I0: 134). Nouwen argues that the ICC judicial system is inherently flawed in the sense that unlike the Nuremberg and Tokyo Tribunals, the ICC does not deal with those who have been vanquished thus providing a battlefield over which protagonists seek to defeat one another (Nouwen 2013: I77).

The ICC allowed the two indictees to pursue their political ends as long as they met their obligations as suspects. It reduced the cases to a political duel among ethnically fragmented politicians. The Court did not remove suspects and later the accused from Kenya's political matrix under the premise that its jurisdiction was restricted to the legal but not politics of the disputed presidential elections. The 2013 elections therefore provided yet another stage for ethno-regional political elite to contest for power against a background of the unfinished business of the 2007 disputed elections. Kenyatta and Ruto framed the ICC and their main presidential challenger, Raila Odinga as enemies of Kenya's sovereignty. They accused Odinga of working in concert with a section of civil society and 'imperialists' to 
fabricate charges against them. By adhering to the Rome Statute, the ICC inadvertently accelerated rather than lowered the tensions in the country's politics. However, had the ICC removed the two from the local political scene it would have inflamed passions among their supporters. It was a catch 22 Situation. It was consistent with the Rome Treaty for suspects and accused persons to be free as long as they honoured summonses and had no arrest warrants against them. However, never before had indicted persons before the ICC been let free until they were acquitted or allowed to attend court proceeding via video link underscoring the fact that the ICC is influenced by geopolitics.

The Rome Statute that provides a legal framework for the ICC came into effect on July I 2002, and like most laws, does not apply retroactively. Significantly, the AU's 2004-2005 Strategic Plan underscores commitment to ensure ratification of the Rome Treaty by all AU member states (Coalition for the International Criminal Court-CICC, n.d.). Indeed the AU Constitutive Act Article 4(h) recognises intervention amidst grave human rights violations in a member state. It reads thus, "the right of the Union to intervene in a Member State pursuant to a decision of the Assembly in respect grave circumstances, namely: war crimes, genocide and crimes against humanity" (Constitutive Act of the African Union 2000). Kenya voluntarily signed the Rome Statute in I999 and ratified it in 2005 thus becoming the 98th State Party. Kenya domesticated the Rome Statute through International Crimes Act 2008, effectively becoming part of Kenya's laws (Republic of Kenya 2008b). The ICC was set up to try the masterminds of egregious crimes including war crimes, crimes against humanity, and genocide. These are often too powerful to be tried by judicial systems in their respective countries (Roth 20I4). Unlike previous ad hoc UN tribunals, the ICC is "...a permanent infrastructure with the ability to monitor crimes and act accordingly as the need arises" (Musila 2009: I2). It targets the powerful since suspects of crimes under the Rome Statute jurisdiction are influential state actors and warlords that have the capacity to compromise national judicial systems.

The ICC addresses mass atrocities committed by individuals. To avoid prosecution ruthless national leaders too often threaten, corrupt or compromise judges and prosecutors at home, but those in The Hague should be beyond the reach of such obstructionism. The ICC is meant as a Court of last resort for victims and survivors who cannot find justice in their own country and as a deterrent to leaders who have little to fear from domestic prosecution (Roth 20I4). 


\section{A Clash between the ICC and 'Africa'}

The ICC is perennially on a collision course with most African rulers primarily because it targets prominent state actors and non-state actors and most of the atrocities under its jurisdiction disproportionately occur in Africa principally owing to weak states characterised by institutional atrophy, tribal politics, and local judiciaries too compromised to impartially dispense justice thus pervasive impunity. Fundamentally, the legacy of slavery, colonialism, and apartheid makes some Africans suspicious of the intentions of multilateral bodies dominated by Westerners the ICC inclusive. In recent memory, before the ICC came into being, grave atrocities seemed to be concentrated in Latin America under military juntas and then Eastern Europe most evocatively in the Balkans in the early I990s. Despite the preponderance of weak judiciaries that are no more than appendages of the executive, African rulers accuse the ICC of unfairly targeting them while ignoring atrocities elsewhere in the world. The accusation evokes the spectre of imperialism and encroachment on the sovereignty of African countries by an institution that these politicians regard as an adjunct of the West to keep them in check. It is trite that sovereignty is not an absolute otherwise there would be no need for international instruments and norms. 'Sovereignty as responsibility' is the norm in international relations. 'This means that where large numbers of populations suffer extreme deprivation and are threatened with death, the international community-obligated by normative standards of humanitarian and human rights-cannot be expected to watch passively and do not respond. Humanitarian intervention then becomes imperative (Deng 2010: 354).

The accusation that the ICC is biased against African rulers is half the truth. Of the I24 members of the Assembly of States Parties, countries that have ratified the Rome Statute 34 are African states, forming the largest bloc. African judges serve within the Court. Africa is also represented by officials in the Office of the Chief Prosecutor headed by a Gambian, Fatou Bensouda. As such, the ICC can hardly be described as anti-African institution based on its composition (Roth 20I4). Moreover, more than 800 civil society groups from Africa are members of the Coalition for the International Criminal Court (CICC) that translates into one third of its global membership (CICC n.d). Importantly, victims of atrocities and human rights groups in Africa support the intervention by the ICC in Africa since it creates hope for justice that is elusive in local judiciaries (HRW 20I4; Roth 20I4).

Proponents of the ICC intervention in African conflicts cite these facts to dispute the notion that the Court was formed with rogue African 
states in mind. Out of the nine African situations, that is, African countries whose citizens currently cases before the ICC, have had before or on whose soil the crimes within the ambit of the ICC jurisdiction were committed, five are self-referral in the sense that the state in question asked the Court to intervene. The wholesale dismissal of the Court as an imperial institution is political. However, the ICC has not been enthusiastic in dealing with mass atrocities in other parts of the world such as Palestine/Israel, Sri Lanka, Myanmar and Iraq thus lending credibility to its critics. Self-referral situations are Uganda, Mali, Central African Republic (CAR) I and II and the Democratic Republic of Congo (DRC). But self-referral cases do not necessarily mean the states concerned are supportive of international criminal justice. These self-referral cases involve rebels fighting against governments and so do not necessarily indicate confidence in the Court by the governments in question (Simmons and Danner 2009: 243). The duplicity with which some Africa rulers relate to the Court is indicative of self-preservation rather than confidence in the ICC. In referring cases involving rebels to the Court, the government runs the risk of having its officials investigated and prosecuted as well thus the word "Situation" refers to the whole gamut of the conflict as opposed to individual cases of wrong doing (Simmons and Danner 2010: 230-23I).

Yoweri Museveni referred ringleaders of the Lord's Resistance Army (LRA), a terror ragtag army that for years committed atrocities in northern Uganda, to the ICC and had LRA's commander Dominic Ongwen handed over to the ICC in 20I5 upon surrendering. However, Museveni was not keen on the Court investigating atrocities by Uganda People's Defence Force (UPDF). He was Uhuru Kenyatta's most vociferous backer in the latter's tirades against the Court and is one of the most acerbic critics of the institution. He is on record having described the ICC as "a bunch of useless people” (BBC News May i2, 20i6).

The Darfur, Sudan and Libya situations are exceptions because the United Nations Security Council (UNSC) referred them to the Court as permitted by the Rome Statute (Hoile 20I4: 66-67). In principle, the ICC has jurisdiction over a crime committed by a citizen of a member state or on the territory of a member state or if the situation is referred to the Court by the UNSC (Roth 20I4). This, in effect, means the ICC "may potentially assume jurisdiction over war crimes, crimes against humanity and genocide committed anywhere in the world" (Kastner 20I0: 13I). Kenya was the first country in which the ICC Chief Prosecutor initiated investigations on his own volition under the proprio motu powers granted by Article 15(3) of the Rome Statute that allows the Prosecutor to initiate an investigation without a referral to the State Party or the UNSC (Rome Statute of International 
Criminal Court 2002; Hoile 20I4: 3I2). Ivory Coast was the second such situation. However, the ICC critics observe that European countries are the greatest funders of the ICC that gives them leverage over the Court and this calls into question its impartiality (Hoile 20I4: I5-I8, 37). Critics take issue the three veto wielding members of UNSC, that is the US, Russia and China for having the power to refer cases to the ICC, as part of the Permanent 5 $\left(\mathrm{P}_{5}\right)$, yet do not recognise the ICC since they have not ratified the Rome Statute. Furthermore, although most European countries are signatories to the Rome Treaty, the fact that major nations such as Russia, Israel, China and India are not, denies the Court international legitimacy and emboldens critics' accusation of selective justice.

\section{The Kenyan Cases before the ICC}

Kenya and most other African countries ratified the Rome Statute apparently as an expression of aversion against impunity and affirmation of the rule of law.

In 2005, the African Commission on Human and People's Rights issued a resolution on ending impunity in Africa and on the domestication and implementation of the Rome Statute of the ICC. It called on civil society organisations in Africa to work together and develop partnerships that further respect the rule of law internationally and strengthen the Statute (CICC n.d.).

Kenya's successive governments beginning with that of Mwai Kibaki and then Uhuru Kenyatta, tried to have cases facing Kenyan suspects either deferred or terminated. The AU launched a strident attack against the Court that threw the credibility and legitimacy of the court into doubt. Kenya ratified the Rome Statute against a background of its post-colonial history characterised by a culture of impunity. Political assassinations, state violence, politically instigated ethnic violence, extrajudicial executions, land grabbing and official grand larceny blot Kenya's post-colonial period but the masterminds and perpetrators did not face justice (Kenya Human Rights Commission (KHRC) I998; KHRC 20II; Republic of Kenya I992; I999; 2008a; 2008c). The Rome Statute finds expression in Kenya's laws under International Crimes Act (Republic of Kenya 20I0; Republic of Kenya 2008b). Significantly, Kenya's laws do not accord immunity to the country's president accused of crimes covered by the Rome Treaty under Article I43(4) of the Constitution of Kenya (Republic of Kenya 2010: 88-89).

Kenya's cases at the ICC highlighted the fact that the institution has a delicate balancing act to do in navigating a dicey terrain of politics, the 
law and geostrategic interests in an attempt to ensure justice for victims of mass atrocities in Africa. It is instructive that since inception in 2002, the ICC has convicted only nine suspects, warlords and a former vice president of Democratic Republic of Congo (DRC) an indication that international criminal justice is skewed, intractable, protracted and expensive, financially and emotionally.

The ICC is likely to lose confidence among Kenyan and other victims following its inability to successfully prosecute suspected masterminds of the 2007-2008 post-election violence. Although Kenyatta had the dubious distinction as the first sitting president to appear before the Court when he was summoned for a "status conference" in October 20I4, the withdrawal of charges against him in December 20I4 and subsequently against Ruto in April 2016 for lack of sufficient evidence to ensure successful prosecutions is two pronged. It dampens hopes of the victims of ever finding justice. It also implies that state power indeed provides ammunition with which to fight against the Court since most of the witnesses inexplicably recanted their testimonies while potential ones, ring leaders of the mungiki militia, died through extrajudicial executions or were disappeared. These people attended a State House meeting and other meetings in which retaliatory attacks against opposition supporters were planned (ICC 20I5b). The judges and prosecutor decried witness tampering in the Ruto case as well (KHRC April 7 20I7). A climate of witness interference in which the government was implicated contributed to the collapse of the two cases besides loopholes in investigations carried out by the prosecutor's office under Luis MorenoOcampo. Human Rights Watch observed that, "with the Kenyatta case closed, the scope of justice the ICC can deliver to Kenya's victims is greatly reduced" (HRW 20I4). Witness interference in the William Ruto case compelled the Court to issue arrest warrants against three Kenyans (ICC 20I5c; ICC 20I3a). Worth noting is that the ICC vacated charges against Kenyatta, Ruto and his co accused, Sang, but did not acquit them. It means that in the event new evidence is found in both cases the charges could be reinstated. This inconclusiveness of the cases and resolution of the 20072008 postelection violence cements the ICC in Kenya's politics for years to come.

\section{A Local Tribunal versus The ICC}

Kenyatta and Ruto voted for a constitutional amendment bill meant to facilitate the formation of a special tribunal in February 2009. However, with the benefit of hindsight, they were not committed to a local resolution to the 2007-2008 post-election atrocities. Before he was indicted, Ruto 
publicly expressed preference for The Hague judicial process as opposed to a special tribunal (The Standard April 5 20II). MPs allied to him and predominantly Kalenjin in ethnic affiliation and drawn from the Rift Valley region, voted against and defeated the motion while singing in rhyme, "Don't be Vague, let's go to The Hague" (Standard Digital February I6 20I2). Kenyatta's fellow Kikuyu allies, almost exclusively from Mount Kenya region, also voted against the bill (The Star March I2 20II). These politicians and civil society preferred the ICC option but for different reasons. Civil society argued that the government had neither the capacity nor political will to set up a credible special tribunal while Ruto and his supporters feared that such a tribunal would be biased against them. At the time, Ruto had not closed ranks with Kenyatta and Kibaki having been on the opposing sides of the 2007 electoral contest, and thus the post-election violence. He feared that a tribunal would be turned into a witch-hunt having been unofficially widely adversely mentioned as the mastermind of atrocities against Kikuyu resident in the Rift Valley region. So strong were the allegations that Ruto voluntarily travelled to The Hague but was unsuccessful in meeting the Chief Prosecutor to "clear his name" and possibly pre-empt being named among the suspected masterminds of the violence (CapitalNews November 4 20I0).

Mutual suspicion among Kenya's political elite and a legacy of impunity paved the way for the ICC intervention in Kenya's conflict. Ruto and allies preferred the ICC not so much because they believed in the rule of law and justice for victims of the 2007-2008 postelection violence as because they thought that it would take as long as "ninety years" before the cases were concluded. Ruto was on record as saying that by that time "we shall all be dead" (Daily Nation October I6 20I3). Kenyatta, Kibaki and supporters imagined that the ICC would implicate Raila Odinga and other prominent Orange Democratic Movement (ODM) party politicians for having called for mass action in protest against what they described as a stolen presidential victory. This politics of recrimination, suspicion, blame casting and expediency saw mass action, a constitutionally guaranteed form of protest, criminalised. Blame shifting played itself out during Ruto's trial. Through his defence, Ruto tried to shift blame and responsibility to Kibaki with regard to the 2007-2008 postelection violence. He accused Kibaki of polarising the country through tribalism after he ascended to power in 2002 that snowballed into violence in 2007-2008 (Daily Nation October 3I 20I3). Furthermore, through his defence and then close ally Charles Keter, Ruto accused some officials in the government in which he serves as Deputy President, carryovers of the Kibaki administration, of scouting for witnesses, bribing and coaching them so as to testify against Ruto before 
the Waki commission and then at the ICC (CapitalNews October I6 20I3).

An ally of Kenyatta, a loquacious and divisive fellow Kikuyu, Moses Kuria, sensationally publicly confessed in 2015 that he and a hawk, a presidential candidate in 2013 and Kibaki hatchet woman, Martha Karua, procured and coached ICC witnesses against Ruto (CapitalNews September 24 20I5). Hence politicians' support for The Hague was neither about justice for the victims of the atrocities nor aversion against impunity. Ruto and supporters feared being implicated in the post-election crimes and so hoped to buy time through the ICC judicial process while Kibaki, Kenyatta and their supporters hoped that the ICC would implicate their opponents in the ODM. The ICC seemed to have been aware of this undercurrent politics. Thus it was even handed in its indictment in the sense that of the "Ocampo six" three were from each side of the political divide during the 2007 electoral contest. This decision also seemed more political than purely legal and its zero conviction rate in Kenya underscores the view. Thereafter the Court indicted four, two from each side following confirmation of charges hearings. This aroused panic and catalysed the closing of ranks by erstwhile ethnic rivals, Kalenjin and Kikuyu.

\section{Conclusion}

The ICC was initially hailed across Kenya's ethnic divide as a welcome intervention in the country's violently disputed presidential elections in 2007. However, Kenyatta and Ruto as ethno-regional "Big Men”, exploited their influence in their respective ethnic groups, Kikuyu and Kalenjin, to whip up ethnic sentiment and mobilise against the ICC and their local political rivals. Once in power, they took advantage of control of state apparatus as leverage over the ICC. The result was derailment of justice for the victims of the 2007-2008 postelection violence. The Kenyan cases demonstrated how difficult it is for the ICC to operate in a polity in which impunity and tribalism hold sway. For the first time, Kenya's kleptocracy appeared vulnerable before a judicial system they could not directly influence and interfere with. However, the collapse of both cases affirmed its capacity to fight back and extricate itself from the jaws of international criminal justice and trump efforts towards attainment of sustainable peace, justice, healing and reconciliation. Although the Rome Statute established the ICC as a legal institution to address the highest forms of crimes that is war crimes, crimes against humanity, and genocide, the Court has to grapple with realpolitik. The controversial election of Kenyatta and Ruto into the presidency, while indicted, the first the world over, exposed the limitations of the ICC until then viewed not only in Kenya but also elsewhere as the bulwark against 
impunity. The less impressive record of the ICC in convicting suspects since inception in 2002 was underscored in the Kenyan cases following non-confirmation of charges, and dropping of charges. As such, there is likelihood that victims of atrocities may lose confidence in the Court leaving them with no recourse for justice especially in Africa characterised by weak and dysfunctional judicial systems.

The challenge that Kenya faces is inability to institutionalise compromise and remove zero sum politics from elections. The rule of law must inform Kenya's public life to ensure resolution of long standing disputes some of whose seeds lie in the colonial period while others were sowed and nurtured in the immediate postcolonial period by Jomo Kenyatta's continued ethnicisation of the state. As evidenced by the results of the 2013 elections that polarised the country further, it is a daunting challenge. Uhuru Kenyatta, a scion of Kenyatta and the core of Kenya's plutocracy and Ruto have no capacity to lead in issues of justice, healing, and reconciliation since they ascended to power on an ethno-regional political axis for selfpreservation, that is, to insulate themselves from prosecution. The two are political creatures and beneficiaries of a political system that stands in need of reform and so have neither the political will nor incentive to transform it. Once more, the 2013 elections underscored the fact that Kenya is so tribally balkanised that it lacks collective norms, and a sense of national identity to guide citizens in electing leaders.

The political elite reify ethnic differences and avariciously exploit them since it is almost impossible for them to be held to account as they pursue rent-seeking opportunities and engage in corruption while shielding under the idiom of tribalism. What appears as anachronistic political behaviour coexists with modernity. Kenya's democratisation process has to contend with a self-replicating plutocratic dynasty with vested interests in the status quo. The international criminal justice system is retributive and so cannot reform Kenya's moral fabric and by extension its flawed politics. That responsibility lies with Kenyans who first have to identify along cross cutting challenges of poverty, unemployment, poor quality of public services, lack of infrastructural facilities, insecurity and identify leadership concerned with their collective wellbeing as opposed to parochial self-interest couched under tribalism. Transcendence from retrogressive primordial politics steeped in ethnicity, regionalism and even religion is sine qua non of holding opportunistic and cynical political elite to account.

Expectations concerning what the ICC could achieve were ambitious and reminiscent of a people that felt hopeless with regard to the ability of the local judiciary to prosecute a rogue political elite but who schizophrenically hoped that the ICC would "fix" politicians from the "enemy" tribe. For 
practical and logistical reasons, the ICC can only do so much in Kenyans' quest for justice and nation building. In fact it could pose a risk to the fragile state by inadvertently getting enmeshed in ethnic divisions. The collapse of the cases against Kenyatta, Ruto and Sang preceded by dropping of charges against three of the "Ocampo six" exposes limitations of a legalistic approach to Kenya's political challenges. What is required is remedial of Kenya's flawed national character through implementation of reform envisaged under the 2010 constitutional dispensation to ensure ethnic inclusivity and long-term political stability a challenge that requires leadership inspired by the imaginary of Kenya's oneness that is currently lacking. The oligarchy has the capacity to impede justice by canvassing support locally through expedient ethnic alliances, across Africa and internationally against the ICC. This spurious form of Pan Africanism entrenches impunity at the expense of victims of mass atrocities in Africa. Retributive justice might be inimical to Kenya's social cohesion but a deeply entrenched culture of impunity that has reproduced violence throughout the country's post-colonial period could easily result in state collapse.

\section{REFERENCES}

Bratton M and van de Walle, N. 1997. Democratic Experiments in Africa. Régime Transitions in Comparative Perspective. Cambridge: Cambridge University Press.

British Broadcasting Corporation (BBC) 2016. "Western envoys in Uganda walk out on Museveni swearing-in" May I2. Online: http://www.bbc. com/news/world-africa-36278479 Accessed December I7 2016.

Brown, S. \& Sriram, C. 20I2. “The Big Fish won't fry themselves: Criminal Accountability for Post-election violence in Kenya”, African Affairs III/443 P. 244-260.

CapitalNews. 20I5. "Karua sues Moses Kuria for defamation" September 24. Online: http://www.capitalfm.co.ke/news/20I5/o9/karua-suesmoses-kuria-for-defamation/ Accessed January 30, 2016. . 20I3. 'PNU plotted to 'crucify' Ruto over poll chaos', October I6. Available at: http://www.capitalfm.co.ke/news/2013/ro/pnu-plotted-to-crucify-ruto-over-poll-chaos/

. 20I0. 'Ruto at The Hague to meet Ocampo', November 4. Available at: http://www.capitalfm.co.ke/news/20Iо/ıI/ruto-at-thehague-to-meet-ocampo/

Chabal, P. and Daloz, J. I999. Africa Works Disorder as Political Instrument. Oxford James Currey. 
Coalition for the International Criminal Court (CICC) (n.d.). Online http:// www.iccnow.org/documents/Africa_and_the_ICC.pdf Accessed April I5 20I5.

Constitutive Act of the African Union. 2000. Online: http://wwwi.uneca.org/ Portals/ngm/Documents/Conventions\%2oand\%2oResolutions/ constitution.pdf Accessed I2 April 2016.

Daily Nation. 2013. "Ruto defence accuses Kibaki of betrayal" October 3I. http://mobile.nation.co.ke/News/Ruto-defence-accuses--Kibaki-of-betrayal-/-/I950946/2055492/-/format/xhtml/-/r5lcv4/-/index.html Accessed I January 2017.

2013. "ICC uncertain on action if Uhuru fails to attend trial", October I6. Available: http://mobile.nation.co.ke/News/ICC-expectsUhuru-to-attend-trial/-/I950946/2035002/-/format/xhtml/-/oyfi52z/-/index.html Accessed i8 December 2016.

Deng, F. 20I0. “From 'Sovereignty as Responsibility' to the 'Responsibility to Protect" in Adekeye Adebajo, Mark Paterson, and Jeremy Sarkin (eds.), Special Issue: Africa's Responsibility to Protect, Global Responsibility to Protect 2, no. 4 (2010), pp.388-4I3.

Hoile, D. 20I4. Justice Denied The Reality of the International Criminal Court; London: The Africa Research Centre.

Human Rights Watch. 20I4. ICC: Hopes for Justice Set Back Prosecution withdraws Kenyatta charges, Online: http://www.hrw.org/ news/20I4/I2/05/icc-hopes-justice-set-back Accessed I January 2015 .

20II. 'Turning Pebbles' Evading Accountability for Post-Election Violence in Kenya. Online: http://www.hrw.org/sites/default/files/reports/kenyaı2ııwebwcover_o.pdf.

Hyden, G. 2006. African Politics in Comparative Perspective. New York. Cambridge University Press.

ICC. 2015. Situation in the Republic of Kenya in the case of the Prosecutor $v$. Uhuru Muigai Kenyatta (Public Redacted Version of "Second Updated Prosecution Pretrial brief" 26 August 2013. ICC-OI/O9-02/II796-cof-AnxA. I9 January 20I5, Online: http://www.icc-cpi.int/iccdocs/doc/docig04539.pdf, 20I5b. Situation in the Republic of Kenya in the case of the Prosecutor v. Uhuru Muigai Kenyatta (Decision on the withdrawal of charges against Mr Kenyatta), I3 March 20I5. Online: http://www.icc-cpi. int/iccdocs/doc/doci936247.pdf 2015c. Situation in the Republic of Kenya in the case of the Prosecutor $v$. 
Paul Gicheru and Philip Kipkoech Bett, Io September 2015. Online: http://www.icc-cpi.int/iccdocs/doc/doc2056890.pdf 2013a. Situation in the Republic of Kenya in the case of the Prosecutor $v$. Walter Osapiri Barasa Under seal ex parte, only available to the Prosecutor and the Registrar Warrant of arrest for Walter Osapiri Barasa. Online: http://www.icc-cpi.int/iccdocs/doc/doci650592.pdf 2013b. Situation in the Republic of Kenya in the case of the Prosecutor v. William Samoei Ruto and Joshua arap Sang (Case Information Sheet). Online: http://www.icc-cpi.int/iccdocs/PIDS/publications/ RutoKosgeySangEng.pdf Accessed I8 March 2017

Jackson, R and Rosberg C. I984. Personal Rule: Theory and Practice in Africa' In Comparative Politics. No. 4 pp. 42I-442.

Institute for War \& Peace Reporting (IWPR) 20I4. Public Confidence in Kenya's Judiciary Plummets Recent dismissals further increase dissatisfaction with national justice system, April I7. Online: https://iwpr.net/ global-voices/public-confidence-kenyas-judiciary-plummets Accessed I2 April 2017.

Karimi, J. and Ochieng', P. I980. The Kenyatta Succession. Nairobi: Transafrica Press.

Kastner, P. 20I0. "Africa-A Fertile Soil for the International Criminal Court?" in Die Friedens-Warte 85(I/2). Pp I3I-I59.

Kenya Human Rights Commission (KHRC). 20I6. "Kenya: Termination of Ruto and Sang Case at the ICC: Witness Tampering means Impunity Prevails over justice again" April 7. Online: http://www.khrc. or.ke/20I5-03-04-I0-37-0I/press-releases/528-kenya-terminationof-ruto-and-sang-case-at-the-icc-witness-tampering-means-impunity-prevkenya-termination-of-ruto-and-sang-case-at-the-icc-witness-tampering-means-impunity-prevails-over-justice-again.html Accessed io December 2016.

. 20II. "Lest We Forget: The Faces of Impunity in Kenya, Nairobi". Online: www.khrc.or.ke

. I998. "Killing the vote State Sponsored Violence and Flawed Elections in Kenya: Nairobi: KHRC."

Musila, G. 2009. Between rhetoric and action The Politics, processes and practice of the ICC's work in the DRC. Pretoria, Institute for Security Studies.

Nouwen, S. 2013. 'The International Criminal Court.' In Curtis, D and Dzinesa, G eds. Peacebuilding, Power, and Politics in Africa. Johannesburg. Wits University Press.

Republic of Kenya. 2008a. Commission of Inquiry into Post-Election Violence 
(CIPEV) or 'the Waki Commission'. Nairobi: Government Printer. Online: http://www.dialoguekenya.org/docs/PEV\%2oReport.pdf 2008b. International Crimes Act. Online: http://www.kenyalaw.org/ Downloads/Acts/The_International_Crimes_Act_2008.pdf Accessed II January, 2017.

2008c. Report of the Independent Review Commission on the General Elections held on 27th December or 'the Kriegler Commission'. Nairobi. Government Printer

. 1999. Report of the Judicial Commission Appointed to Inquire into Tribal Clashes in Kenya, 'Akiwumi Commission' Nairobi: Government printer.

. I992. Report of parliamentary Select Committee to investigate Ethnic Clashes in Western and Other Parts of Kenya, 'Kiliku Commission.' Nairobi: Government Printer.

. 20I0. The Proposed Constitution of Kenya': Nairobi: Government Printer

Roth, K. 20I4. Africa Attacks the International Criminal Court. Online: http:// www.hrw.org/news/20I4/oI/I4/africa-attacks-international-criminal-Court

Russell, A. 1999. Big Men Little People Encounters in Africa. London: Macmillan Publishers.

Shilaho, W. 20I4. "I Do Not Know Who Won the Elections: How Not to Conduct Elections and Kenya's Democratic Reversals”. In Politeia 33(3). 2013. "Old Wine in New Skins: Kenya's 2013 Elections and the Triumph of the Ancien Régime". In Journal of African Elections special Issue The Evolving Role of Elections in Africa I2: 3; Dec 2013. pp 89II9.

. 20I5. "Third Time Lucky? Devolution and State Restructure under Kenya's 20I0 Constitutional Dispensation”. In LeVan, A. Fashagba McMahon, E (eds) African State Governance Subnational Politics and National Power; Basingstoke, Palgrave Macmillan.

Simmons, B and Danner, A. 2oro. "Credible Commitments and the International Criminal Court" In International Organization 64(2): 225256 .

. 2009. "The International Criminal Court" In Armstrong, D (ed) Routledge Handbook of International Law, Routledge: New York.

Standard Digital. 20I2. "Ruto in dramatic face-off with Raila over ICC", February I6. Available at: http://www.standardmedia.co.ke/business/ article/2000052212/ruto-in-dramatic-face-off-with-raila-over-ic- 


\section{c?page $\mathrm{No}=4$}

The Final Report of the TJRC of Kenya 2013. Online: http://digitalcommons. law.seattleu.edu/tjrc/ Accessed iI December 20I6.

The Star. 20II. "How MPs rejected the proposed Special Tribunal for Kenya Bill", March I2. Available at: http://www.the-star.co.ke/news/article-90352/how-mps-rejected-proposed-special-tribunal-kenya-bill Accessed 20 March 2017.

2013. "How TJRC Land Chapter was Censored" June 4. Online: http://www.the-star.co.ke/news/article-I22777/how-tjrc-land-chapter-was-censored Accessed June 7, 2013.

. 2013. "Missing Paragraphs In The TJRC Report On The Land Question" June 3. Online: http://www.the-star.co.ke/news/article-I22862/missing-paragraphs-tjrc-report-land-question Accessed 7 December 2017.

Van de Walle, N. I994. "Neopatrimonialism and Democracy in Africa with an Illustration from Cameroon". In Widner, J. (ed) Economic Change and Political Liberalism in Sub-Saharan Africa. The John Hopkins University.

Widner, J. I994. "Political Reform in Anglophone and Francophone African Countries”. In Widner, J. (ed) Economic Change and Political Liberalism in Sub-Saharan Africa. Baltimore: The John Hopkins University. 


\begin{abstract}
Did the entry by the International Criminal Court (ICC) into the 2007-2008 postelection dispute ruffle feathers among Kenya's politicians and influence the results of the 2013 elections? This article argues that the indictment of prominent Kenyans by the ICC for atrocities committed during the postelection violence was the first attempt to break a vicious cycle of impunity deeply entrenched in the country's body politic. However, the indictees exploited cases against them to exacerbate ethnic fault lines, polarise the country and ensure the controversial victory by Uhuru Kenyatta and William Ruto during the 2013 elections despite facing egregious charges before the ICC. Crucially, the ICC precipitated uncertainty and trepidation among Kenya's kleptocrats in power since I963, the year of Kenya's independence. Kenyatta's controversial presidential victory in 2013 was both personal and oligarchic as it ensured continued stranglehold on Kenya's political and economic spheres by a self-reporuding plutocracy. With control of state apparatus, Kenyatta and Ruto successfully fought back against the threat posed by the ICC. The article analyses ICC politics impunity, and ethnic politics through the prism of Kenya's cases before the ICC.
\end{abstract}

\title{
KEYWORDS
}

Kenya; ICC; Africa; international criminal justice; ethnicity; tribalism; impunity; violence; crime; oligarchy 